\title{
Isotope Effects on the Enzymatic and Non-Enzymatic Reactions of Chorismate
}

\author{
S. Kirk Wright ${ }^{\dagger}$, Michael S. DeClue ${ }^{\ddagger}$, Ajay Mandal ${ }^{\ddagger}$, Lac Lee $^{\dagger}$, Olaf Wiest $^{\S}$, W. Wallace \\ Cleland ${ }^{\dagger},{ }^{*}$, and Donald Hilvert ${ }^{\ddagger},{ }^{\star}$
}

$\dagger$ Institute for Enzyme Research and Department of Biochemistry, University of Wisconsin, 1710 University Avenue, Madison, Wisconsin 53705, USA ${ }^{\star}$ Laboratory of Organic Chemistry, Swiss Federal Institute of Technology, ETH Hönggerberg, CH-8093 Zürich, Switzerland $\$$ Department of Chemistry and Biochemistry, University of Notre Dame, Notre Dame, Indiana 46556-5670, USA

\begin{abstract}
The important biosynthetic intermediate chorismate reacts thermally by two competitive pathways, one leading to 4-hydroxybenzoate via elimination of the enolpyruvyl side chain, and the other to prephenate by a facile Claisen rearrangement. Measurements with isotopically labeled chorismate derivatives indicate that both are concerted sigmatropic processes, controlled by the orientation of the enolpyruvyl group. In the elimination reaction of $\left[4-^{2} \mathrm{H}\right]$ chorismate, roughly $60 \%$ of the label was found in pyruvate after $3 \mathrm{~h}$ at $60^{\circ} \mathrm{C}$. Moreover, a $1.846 \pm 0.057^{2} \mathrm{H}$ isotope effect for the transferred hydrogen atom and a $1.0374 \pm 0.0005{ }^{18} \mathrm{O}$ isotope effect for the ether oxygen show that the transition state for this process is highly asymmetric, with hydrogen atom transfer from $\mathrm{C} 4$ to $\mathrm{C} 9$ significantly less advanced than $\mathrm{C}-\mathrm{O}$ bond cleavage. In the competing Claisen rearrangement, a very large ${ }^{18} \mathrm{O}$ isotope effect at the bond-breaking position $(1.0482 \pm 0.0005)$ and a smaller ${ }^{13} \mathrm{C}$ isotope effect at the bond-making position (1.0118 \pm 0.0004$)$ were determined. Isotope effects of similar magnitude characterized the transformations catalyzed by evolutionarily unrelated chorismate mutases from Escherichia coli and Bacillus subtilis. The enzymatic reactions, like their solution counterpart, are thus concerted [3,3]-sigmatropic processes in which $\mathrm{C}-\mathrm{C}$ bond formation lags behind $\mathrm{C}-\mathrm{O}$ bond cleavage. However, as substantially larger ${ }^{18} \mathrm{O}$ and smaller ${ }^{13} \mathrm{C}$ isotope effects were observed for a mutant enzyme in which chemistry is fully rate determining, the ionic active site may favor a somewhat more polarized transition state than that seen in solution.
\end{abstract}

The unimolecular rearrangement of chorismate (1) to prephenate (2) is a key step in the biosynthesis of the aromatic amino acids tyrosine and phenylalanine (Scheme 1). Formally, this reaction can be described as a pericyclic Claisen rearrangement, a 3,3-sigmatropic process that is rarely exploited in cellular metabolism. Secondary tritium isotope effects have suggested that the uncatalyzed reaction is concerted but asynchronous, with $\mathrm{C}-\mathrm{O}$ bond cleavage preceding $\mathrm{C}-\mathrm{C}$ bond fomation, ${ }^{1}$ while stereochemical studies have established a chair-like geometry for the transition state. ${ }^{2}$ These conclusions are supported by RHF/6-31* calculations.

Chorismate mutases accelerate the chorismate to prephenate rearrangement more than a million fold. ${ }^{4}$ Crystallographic studies have shown that these enzymes fall into two structurally distinct classes. ${ }^{5}$ The overwhelming majority of chorismate mutases belong to the AroQ family, whose

\footnotetext{
*To whom correspondence should be addressed at cleland @enzyme.wisc.edu (W.W.C.) hilvert@org.chem.ethz.ch (D.H.)

Supporting Information Available. Coordinates and computational details for calculation of the theoretical isotope effects, plus derivations of equations 2 and 3 (10 pages). This material is available free of charge via the Internet at http://pubs.acs.org.
} 
prototype is the allhelix bundle chorismate mutase domain of the Escherichia coli chorismate mutase-prephenate dehydratase (EcCM). ${ }^{6}$ The AroH class, exemplified by the monofunctional chorismate mutase from Bacillus subtilis (BsCM), has a trimeric pseudo $\alpha / \beta$-barrel topology with three active sites at the subunit interfaces. ${ }^{7,} 8$ Despite their different scaffolds, the enzymes have similarly functionalized active sites, activities, and inhibition profiles. ${ }^{5}$

The origins of the catalytic rate enhancement achieved by chorismate mutases have been elusive. The enzymatic reactions, like their uncatalyzed counterpart, proceed via a chair-like transition state. ${ }^{2}$ However, efforts to better define the structure of this species at the active site of an AroQ enzyme, the bifunctional chorismate mutase-prephenate dehydrogenase from $E$. coli, were thwarted by suppression of the secondary tritium isotope effect, most likely due to a large forward commitment. ${ }^{1}$ More recently, heavy atom isotope effects were determined for the BsCM-catalyzed reaction. ${ }^{9}$ The large ${ }^{18} \mathrm{O}$ isotope effect at $\mathrm{O} 7$ (ca. $5 \%$ ), the bond-breaking position, and the small, normal isotope effect at $\mathrm{C} 1$ (ca. 0.6\%), the site of bond-making, suggested that chemistry is significantly rate determining for the AroH enzyme and that the enzymatic reaction also proceeds through a concerted but asymmetric transition state.

In the present study, we have extended our work on BsCM by determining the heavy atom isotope effect at $\mathrm{C} 9$ in the vinyl side chain of chorismate, providing additional information about the bond-making process. We also report heavy atom isotope effects at $\mathrm{C} 1$ and $\mathrm{O} 7$ for the EcCM-catalyzed reaction and for the uncatalyzed rearrangement of chorismate. Our results indicate that both enzyme-catalyzed reactions, as well as the spontaneous thermal reaction, proceed concertedly through similar asynchronous pericyclic transition states. Furthermore, analysis of the non-enzymatic conversion of chorismate to 4-hydroxybenzoate shows that this side reaction, which competes with the Claisen rearrangement, also proceeds via a pericyclic transition state.

\section{MATERIALS AND METHODS}

\section{General methods and materials}

All reactions were carried out in flame-dried glassware. THF and $\mathrm{Et}_{2} \mathrm{O}$ were dried by distillation from sodium benzophenone ketyl. $\mathrm{CH}_{2} \mathrm{Cl}_{2}$ was dried by distillation from $\mathrm{CaH}_{2}$. All other chemicals and solvents were reagent grade and used as received. Chromatographic purifications were performed with Kieselgel 60, 230-400 mesh silica gel (Fluka). Eluent mixtures are reported as v:v percentages of the minor constituent in the major constituent. Methyl $\left[7-{ }^{12} \mathrm{C}\right]$ shikimate, ${ }^{10}$ ethyl $\left[7-{ }^{13} \mathrm{C}\right]$ shikimate ${ }^{10}$ and potassium $\left[3-{ }^{13} \mathrm{C}\right]$ phosphoenolpyruvate ${ }^{11}$ were prepared by published methods. Unlabeled chorismic acid was isolated from Escherichia coli strain KA12 and purified by reverse phase chromatography. 12 Mixtures of $\left[10-{ }^{12} \mathrm{C}\right]$ chorismic acid and $\left[7-{ }^{18} \mathrm{O}, 10-{ }^{13} \mathrm{C}\right]$ chorismic acid (ca. 99:1) and $\left[10-{ }^{12} \mathrm{C}\right]$ chorismic acid and $\left[1,10-{ }^{13} \mathrm{C}\right]$ chorismic acid (ca. 99:1) were prepared chemoenzymatically as previously described. ${ }^{10}$ Wild-type BsCM $,{ }^{13} \mathrm{C} 75 \mathrm{~S} \mathrm{BsCM},{ }^{13}$ and $\mathrm{EcCM}^{14}$ were produced and purified as reported.

\section{[10- $\left.{ }^{12} \mathrm{C}\right]$ Chorismic acid (1a)}

$\mathrm{NaOH}(1 \mathrm{M}, 0.88 \mathrm{~mL}, 0.88 \mathrm{mmol})$ was added to a solution of methyl[7- $\left.{ }^{12} \mathrm{C}\right]$ shikimate $^{10}$ in a 1:1 mixture of THF and $\mathrm{H}_{2} \mathrm{O}(12 \mathrm{~mL})$. The mixture was stirred at $23{ }^{\circ} \mathrm{C}$ for $8 \mathrm{~h}$. After the removal of THF by distillation in vacuo, the aqueous mixture was lyophilized. The mono sodium salt of ATP $(0.68 \mathrm{~g}, 1.2 \mathrm{mmol})$ was dissolved in Tris- $\mathrm{HCl}(24.0 \mathrm{~mL}, 50 \mathrm{mM})$ while maintaining the $\mathrm{pH}$ of the solution between 6.5 and 9.0. To this solution were added FMN (50 $\mathrm{mg}, 0.09 \mathrm{mmol})$, the unlabeled monopotassium salt of phosphoenolpyruvate $(0.57 \mathrm{~g}, 2.43$ $\mathrm{mmol}$ ), a solution of $\mathrm{KCl}\left(1.0 \mathrm{M}\right.$ aqueous, $2.0 \mathrm{~mL}$ ), a solution of $\mathrm{MgSO}_{4}(1.0 \mathrm{M}$ aqueous, 0.2 $\mathrm{mL}$ ), and a solution of the sodium shikimate in Tris- $\mathrm{HCl}(4.4 \mathrm{~mL}, 50 \mathrm{mM}, \mathrm{pH}$ 8.2). KA12/ 
pKAD50 extract ${ }^{15}$ (30 mL, corresponding to the lysate of ca. $40 \mathrm{mg} / \mathrm{mL}$ ) was added, and the $\mathrm{pH}$ of the resulting mixture was adjusted to 8.1 using $\mathrm{NaOH}(1 \mathrm{~N})$. Finally, sodium dithionite $(85 \mathrm{mg}, 0.48 \mathrm{mmol})$ was added. The resulting solution was sealed and gently stirred at $23 \mathrm{C}$ for $1 \mathrm{~h}$. The reaction mixture was then filtered through an Amicon 10K cutoff ultrafiltration membrane at $4 \mathrm{C}$. When nearly dry, the membrane was washed with Tris- $\mathrm{HCl}(25 \mathrm{~mL}, 50 \mathrm{mM}$, $\mathrm{pH}$ 8.2). The combined filtrate was acidified to $\mathrm{pH} 1.5$ and extracted with EtOAc $(6 \times 20 \mathrm{~mL})$. The combined extracts were dried over $\mathrm{Na}_{2} \mathrm{SO}_{4}$ and carefully concentrated in vacuo (while the bath for the rotary evaporator was maintained at ca. $20^{\circ} \mathrm{C}$ ). The residue was dissolved in a 1:1 mixture of $\mathrm{H}_{2} \mathrm{O}$ and $\mathrm{MeOH}$ and filtered through a pad of charcoal. The filtrate was lyophilized to provide crude labeled chorismic acid $(80.0 \mathrm{mg}, 40 \%)$. The residue was further purified by $\mathrm{C}-18$ reverse phase silica gel chromatography $\left(10 \mathrm{mM}\right.$, ammonium acetate buffer). $R_{\mathrm{f}}(1 \mathrm{M}$, ammonium acetate buffer) $0.89 ;{ }^{1} \mathrm{H}$ NMR $\left(300 \mathrm{MHz}, \mathrm{D}_{2} \mathrm{O}\right): \delta 4.64(\mathrm{~d}, J=2.0 \mathrm{~Hz}, 1 \mathrm{H}), 4.84$ $(\mathrm{m}, 1 \mathrm{H}), 4.97(\mathrm{dd}, J=10.0,2.0 \mathrm{~Hz}, 1 \mathrm{H}), 5.26(\mathrm{~d}, J=2.0 \mathrm{~Hz}, 1 \mathrm{H}), 6.02(\mathrm{dd}, J=10,2.0 \mathrm{~Hz}$, $1 \mathrm{H}), 6.38(\mathrm{dt}, J=8.0,2.0 \mathrm{~Hz}, 1 \mathrm{H}), 6.65(\mathrm{~m}, 1 \mathrm{H})$; MS (ESI), $m / z 451\left(2 \mathrm{M}-\mathrm{H}^{+}\right), 225\left(\mathrm{M}-\mathrm{H}^{+}\right)$, $207\left(\mathrm{M}-\mathrm{H}_{3} \mathrm{O}^{+}\right)$.

\section{$\left[{ }^{9-13} \mathrm{C}, 10-{ }^{13} \mathrm{C}\right]$ Chorismic acid $(1 \mathrm{~d})$}

This compound was prepared chemoenzymatically from ethyl [7-13C] shikimate $^{10}$ (25 mg, $0.12 \mathrm{mmol})$ and $\left[3-{ }^{13} \mathrm{C}\right]$ phosphoenolpyruvate ${ }^{11}(58.5 \mathrm{mg}, 0.26 \mathrm{mmol})$, as described for $\left[10-{ }^{12} \mathrm{C}\right]$ chorismic acid 1a. $(8.2 \mathrm{mg}, 30 \%) .{ }^{1} \mathrm{H}$ NMR $\left(300 \mathrm{MHz}, \mathrm{D}_{2} \mathrm{O}\right): \delta 4.53(\mathrm{~m}, 1 \mathrm{H}), 5.05$ $(\mathrm{dd}, J=12.6,1.6 \mathrm{~Hz}, 1 \mathrm{H}), 5.17(\mathrm{~m}, 1 \mathrm{H}), 5.71(\mathrm{~m}, 1 \mathrm{H}), 6.05(\mathrm{~m}, 1 \mathrm{H}), 6.35(\mathrm{~m}, 1 \mathrm{H}), 6.86(\mathrm{~m}$, $1 \mathrm{H})$; MS (ESI), $m / z 227\left(\mathrm{M}-\mathrm{H}^{+}\right), 209\left(\mathrm{M}-\mathrm{H}_{3} \mathrm{O}^{+}\right)$. $\left[10-{ }^{12} \mathrm{C}\right]$ chorismic acid and $\left[7-{ }^{18} \mathrm{O}, 10-{ }^{13} \mathrm{C}\right]$ chorismic acid were mixed in ca. 99:1 ratio. To ensure decomposition of all contaminating prephenate prior to determination of the isotope effect, the mixture was treated with $300 \mu \mathrm{L}$ of $5 \mathrm{~N} \mathrm{HCl}$. After $1 \mathrm{~h}$ on ice, the chorismate acid solution was brought to $\mathrm{pH}$ to 6.5 by addition of $\mathrm{KOH}$ and sparged with moist $\mathrm{CO}_{2}$-free nitrogen gas.

\section{3-((3aS,5R,6R,6aS)-6-Benzyloxy-2,2-dimethyl-tetrahydro-furo[2,3-d][1,3]dioxol-5-yl)-2- (diethoxy-phosphoryl)-propionic acid methyl ester (4)}

Triflic anhydride (1.14 $\mathrm{mL}, 6.8 \mathrm{mmol})$ was added drop-wise over $10 \mathrm{~min}$ to a stirred solution of 1,2-O-isopropylidene-3- $O$-benzyl-D-arabinofuranose $(3)^{16}(1.45 \mathrm{~g}, 5.2 \mathrm{mmol})$ in dry $\mathrm{CH}_{2} \mathrm{Cl}_{2}(15 \mathrm{~mL})$ and pyridine $(920 \mu \mathrm{L}, 11.4 \mathrm{mmol})$ at $-30{ }^{\circ} \mathrm{C}$ under a flow of nitrogen. After $15 \mathrm{~min}$ at $-30^{\circ} \mathrm{C}$ the reaction was quenched by the addition of $\mathrm{H}_{2} \mathrm{O}(5 \mathrm{~mL})$. The resulting mixture was diluted with $\mathrm{CH}_{2} \mathrm{Cl}_{2}(20 \mathrm{~mL})$, washed with aqueous $\mathrm{NaH}_{2} \mathrm{PO}_{4}(1.0 \mathrm{M}, 5 \mathrm{~mL})$, dried over $\mathrm{MgSO}_{4}$ and evaporated to afford $2.0 \mathrm{~g}(93 \%)$ of the triflate as a light pink oil. This intermediate is highly reactive and should be used as quickly as possibly. The crude triflate $(2.0 \mathrm{~g}, 4.8 \mathrm{mmol})$ was dissolved in dry DMF $(8.5 \mathrm{~mL})$ and added to the ylid of methyl P,Pdiethylphosphonacetate, prepared in advance by adding methyl P,P-diethylphosphonacetate $(1.54 \mathrm{~mL}, 8.35 \mathrm{mmol})$ in dry DMF $(8.5 \mathrm{~mL})$ to a stirred suspension of sodium hydride (300 $\mathrm{mg}, 7.5 \mathrm{mmol})$ in dry DMF $(20 \mathrm{~mL})$ at $0{ }^{\circ} \mathrm{C}$. After addition of 15 -crown-5 ( 3 drops), the mixture was stirred overnight at room temperature to furnish a dark solution. The reaction was subsequently cooled to $0{ }^{\circ} \mathrm{C}$, quenched with aqueous $\mathrm{NaH}_{2} \mathrm{PO}_{4}(1.0 \mathrm{M}, 25 \mathrm{~mL})$, and then extracted with $\mathrm{CHCl}_{3}(3 \times 40 \mathrm{~mL})$. The combined $\mathrm{CHCl}_{3}$ layers were washed with $\mathrm{H}_{2} \mathrm{O}(15$ $\mathrm{mL}$ ), dried over $\mathrm{MgSO}_{4}$, and evaporated to yield a red oil. Purification by flash chromatography with silica absorbent (EtOAc/hexanes, 1:1) gave $1.65 \mathrm{~g} \mathrm{(73 \% )} \mathrm{of} \mathbf{4}$ as a mixture of diastereomers. ${ }^{1} \mathrm{H}$ NMR $\left(300 \mathrm{MHz}, \mathrm{CDCl}_{3}\right): \delta 1.28-1.37(\mathrm{~m}, 18 \mathrm{H}), 1.51(\mathrm{~s}, 3 \mathrm{H}), 1.55(\mathrm{~s}, 3 \mathrm{H})$, 2.15-2.30 (m, $2 \mathrm{H}), 2.35-2.55(\mathrm{~m}, 2 \mathrm{H}), 3.04-3.20(\mathrm{~m}, 1 \mathrm{H}), 3.34-3.50(\mathrm{~m}, 1 \mathrm{H}), 3.68-3.86(\mathrm{~m}$, $8 \mathrm{H}), 4.06-4.22(\mathrm{~m}, 10 \mathrm{H}), 4.54-4.66(\mathrm{~m}, 6 \mathrm{H}), 5.84(\mathrm{~d}, J=3.9 \mathrm{~Hz}, 1 \mathrm{H}), 5.89(\mathrm{~d}, J=3.6 \mathrm{~Hz}, 1 \mathrm{H})$, 7.28-7.40 (m, 10H). HRMS- MALDI ${ }^{+}[\mathrm{M}+\mathrm{Na}]^{+}$: calcd $\left(\mathrm{C}_{22} \mathrm{H}_{33} \mathrm{NaO}_{9} \mathrm{P}\right) 495.1760$; found 495.1755 . 


\section{2-(Diethoxy-phosphoryl)-3-((3aS,5R,6R,6aS)-6-hydroxy-2,2-dimethyl-tetrahydro-furo[2,3-d] [1,3]dioxol-5-yl)-propionic acid methyl ester (5)}

Compound 4 (1.65 g, $3.5 \mathrm{mmol}$ ) was dissolved in $40 \mathrm{~mL}$ methanol, and stirred with $\mathrm{H}_{2} \mathrm{O}$ (2.0 $\mathrm{mL})$, ammonium formate $(1.0 \mathrm{~g}, 15.8 \mathrm{mmol})$ and $10 \% \mathrm{Pd} / \mathrm{C}(1.13 \mathrm{~g})$ at $50{ }^{\circ} \mathrm{C}$ for $2 \mathrm{~h}$. After cooling to room temperature and filtering off the $\mathrm{Pd} / \mathrm{C}$, the solution was diluted with $\mathrm{H}_{2} \mathrm{O}(10$ $\mathrm{mL})$ and concentrated to ca. $10 \mathrm{~mL}$ under reduced pressure. Extraction with $\mathrm{CHCl}_{3}(3 \times 40$ $\mathrm{mL}$ ), followed by drying over $\mathrm{MgSO}_{4}$ and evaporation of the solvent, afforded $1.26 \mathrm{~g}(94 \%)$ of $\mathbf{5}$ as a mixture of diastereomers as a clear oil. This material was used in the next step without further purification. ${ }^{1} \mathrm{H}$ NMR $\left(300 \mathrm{MHz}, \mathrm{CDCl}_{3}\right): \delta 1.27-1.36(\mathrm{~m}, 18 \mathrm{H}) 1.50(\mathrm{~s}, 3 \mathrm{H}), 1.54(\mathrm{~s}$, $3 \mathrm{H}), 2.16-2.51(\mathrm{~m}, 4 \mathrm{H}), 3.02-3.50(\mathrm{~m}, 2 \mathrm{H}), 3.73(\mathrm{~s}, 3 \mathrm{H}), 3.76(\mathrm{~s}, 3 \mathrm{H}), 3.96-4.18(\mathrm{~m}, 12 \mathrm{H}), 4.51$ $(\mathrm{s}, 1 \mathrm{H}), 4.53(\mathrm{~s}, 1 \mathrm{H}), 5.86(\mathrm{~d}, J=3.9 \mathrm{~Hz}, 1 \mathrm{H}), 5.90(\mathrm{~d}, J=3.6 \mathrm{~Hz}, 1 \mathrm{H}) . \mathrm{HRMS}^{-M A L D I}{ }^{+}[\mathrm{M}$ $+\mathrm{Na}]^{+}$: calcd $\left(\mathrm{C}_{15} \mathrm{H}_{27} \mathrm{NaO}_{9} \mathrm{P}\right) 405.1290$; found 405.1289 .

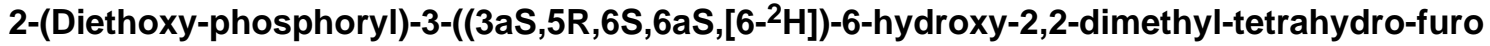 [2,3- d][1,3]dioxol-5-yl)-propionic acid methyl ester (6)}

Crude 5 (1.26 g, $3.3 \mathrm{mmol}$ ) was stirred with phosphorus pentoxide (765 mg, $2.7 \mathrm{mmol})$ in dry DMF $(12.6 \mathrm{~mL})$ and dry DMSO $(1.2 \mathrm{~mL})$ under nitrogen at $70{ }^{\circ} \mathrm{C}$ for $3.5 \mathrm{~h}$. After cooling to room temperature and dilution with $\mathrm{H}_{2} \mathrm{O}(40 \mathrm{~mL})$, the mixture was extracted with $\mathrm{CHCl}_{3}(3 \times$ $50 \mathrm{~mL})$. The combined $\mathrm{CHCl}_{3}$ layers were washed with $\mathrm{H}_{2} \mathrm{O}(15 \mathrm{~mL})$, dried over $\mathrm{MgSO}_{4}$, and evaporated to give $1.1 \mathrm{~g}(88 \%)$ of the crude ketone as a light yellow oil. The latter was dissolved in methanol $(27.0 \mathrm{~mL})$ and water $(3.0 \mathrm{~mL})$ and stirred for $5 \mathrm{~min}$ at $0{ }^{\circ} \mathrm{C}$. Sodium borodeuteride $(590 \mathrm{mg}, 14.1 \mathrm{mmol})$ was then slowly added to the solution over a $5 \mathrm{~min}$ period. After stirring at $0{ }^{\circ} \mathrm{C}$ for $1 \mathrm{~h}$ the mixture was diluted with $\mathrm{H}_{2} \mathrm{O}(20 \mathrm{~mL})$ and extracted with $\mathrm{CHCl}_{3}(3 \times 50$ $\mathrm{mL}$ ). The combined $\mathrm{CHCl}_{3}$ layers were dried over $\mathrm{MgSO}_{4}$ and evaporated to yield $940 \mathrm{mg}$ $(85 \%)$ of $\mathbf{6}$ as a mixture of diastereomers as a clear oil. This material was used inthe next step without further purification. ${ }^{1} \mathrm{H}$ NMR $\left(300 \mathrm{MHz}, \mathrm{CDCl}_{3}\right): \delta 1.27-1.39(\mathrm{~m}, 18 \mathrm{H}), 1.59(\mathrm{~s}, 3 \mathrm{H})$, $1.62(\mathrm{~s}, 3 \mathrm{H}), 2.22-2.51(\mathrm{~m}, 4 \mathrm{H}), 3.14-3.29(\mathrm{~m}, 1 \mathrm{H}), 3.32-3.48(\mathrm{~m}, 1 \mathrm{H}), 3.74(\mathrm{~d}, J=0.6 \mathrm{~Hz}$, $3 \mathrm{H}), 3.76(\mathrm{~d}, J=0.6 \mathrm{~Hz}, 3 \mathrm{H}), 3.92-4.08(\mathrm{~m}, 2 \mathrm{H}), 4.10-4.22(\mathrm{~m}, 8 \mathrm{H}), 4.60(\mathrm{~s}, 1 \mathrm{H}), 4.61(\mathrm{~s}, 1 \mathrm{H})$, $5.69(\mathrm{~d}, J=4.2,1 \mathrm{H}), 5.72(\mathrm{~d}, J=4.2 \mathrm{~Hz}, 1 \mathrm{H})$. HRMS-MALDI ${ }^{+}[\mathrm{M}+\mathrm{Na}]^{+}$: calcd $\left(\mathrm{C}_{15} \mathrm{H}_{26} \mathrm{DNaO}_{9} \mathrm{P}\right)$ 406.1352; found 406.1352 .

\section{2-(Diethoxy-phosphoryl)-3-((3aS,4R,6aS,[3a-2 $\mathrm{H}])-6$-hydroxy-2,2-dimethyl-tetrahydro-furo [3,4- d][1,3]dioxol-4-yl)-propionic acid methyl ester (7)}

Compound 6 (940 mg, 2.45 mmol) was mixed with Dowex-50WX8-200 (2.4 g,washed with acetone three times and dried under vacuum for $30 \mathrm{~min})$ in dry acetone $(25 \mathrm{~mL})$ and stirred at room temperature under nitrogen overnight. The solution was then filtered and the resin washed with acetone $(3 \times 35 \mathrm{~mL})$. The combined acetone layers were evaporated to yield $823 \mathrm{mg}(88$ $\%$ ) of $\mathbf{7}$ as a mixture of diastereomers as a light yellow oil. This material was used in the next step without further purification. ${ }^{1} \mathrm{H}$ NMR $\left(300 \mathrm{MHz}, \mathrm{CDCl}_{3}\right): \delta 1.24-1.37(\mathrm{~m}, 18 \mathrm{H}), 1.44(\mathrm{~s}$, $3 \mathrm{H}), 1.45(\mathrm{~s}, 3 \mathrm{H}), 2.12-2.50(\mathrm{~m}, 4 \mathrm{H}), 3.11-3.40(\mathrm{~m}, 2 \mathrm{H}), 3.75(\mathrm{~s}, 6 \mathrm{H}), 4.06-4.24(\mathrm{~m}, 10 \mathrm{H}), 4.58$ (s, 2H), 5.32 (s, 2H). HRMS-MALDI ${ }^{+}[\mathrm{M}+\mathrm{Na}]^{+}$: calcd $\left(\mathrm{C}_{15} \mathrm{H}_{26} \mathrm{DNaO}_{9} \mathrm{P}\right) 406.1352$; found 406.1358.

\section{Methyl 3,4-[4-2 $\mathrm{H}](0-$-Isopropylidene)shikimate (8)}

A solution of $7(820 \mathrm{mg}, 2.15 \mathrm{mmol})$ in dry methanol $(60 \mathrm{~mL})$ was added dropwise to precooled solution of sodium methoxide, which was prepared by adding dry methanol $(60 \mathrm{~mL})$ to sodium ( $160 \mathrm{mg}, 7.0 \mathrm{mmol}$, washed 1 time with hexanes), over 30 min under a flow of nitrogen while maintaining the temperature at $0{ }^{\circ} \mathrm{C}$. The mixture was warmed to room temperature and stirred overnight. The reaction was then quenched by addition of a saturated aqueous solution of $\mathrm{NaHCO}_{3}(30 \mathrm{~mL})$ and extracted with $\mathrm{Et}_{2} \mathrm{O}(3 \times 60 \mathrm{~mL})$. The combined $\mathrm{Et}_{2} \mathrm{O}$ layers were washed with $\mathrm{H}_{2} \mathrm{O}(20 \mathrm{~mL})$, dried over $\mathrm{MgSO}_{4}$, and evaporated to provide a 
light yellow oil. Purification by flash chromatography with silica absorbent (EtOAc/hexanes, 3:7) yielded $132 \mathrm{mg}(27 \%)$ of 8 as a clear oil. ${ }^{1} \mathrm{H}$ NMR $\left(300 \mathrm{MHz}, \mathrm{CDCl}_{3}\right): \delta 1.40(\mathrm{~s}, 3 \mathrm{H})$, $1.45(\mathrm{~s}, 3 \mathrm{H}), 2.03(\mathrm{br} \mathrm{s}, 1 \mathrm{H}), 2.25(\mathrm{ddt}, J=16.5,8.4,1.8 \mathrm{~Hz}, 1 \mathrm{H}), 2.80$ (ddt, $J=17.4,4.8,0.9$ $\mathrm{Hz}, 1 \mathrm{H}), 3.77$ (s, 3H), 3.90 (pent, $J=3.9 \mathrm{~Hz}, 1 \mathrm{H}), 4.74(\mathrm{~d}, J=3.3 \mathrm{~Hz}, 1 \mathrm{H}), 6.90-6.94(\mathrm{~m}$, 1H). ${ }^{13} \mathrm{C}$ NMR $\left(75 \mathrm{MHz}, \mathrm{CD}_{2} \mathrm{Cl}_{2}\right): \delta 25.9,28.1,29.8,52.3,69.0,72.6,77.9(\mathrm{t}, J=22.5 \mathrm{~Hz})$, 109.9, 130.9, 134.2, 166.9. HRMS-ESI ${ }^{+}[\mathrm{M}+\mathrm{Na}]^{+}$: calcd $\left(\mathrm{C}_{11} \mathrm{H}_{15} \mathrm{DNaO}_{5}\right) 252.0957$; found 252.0951 .

\section{Methyl [4-2 $\left.{ }^{2}\right]$ Shikimate (9)}

Compound 8(130 mg, $0.58 \mathrm{mmol}$ ) was mixed with Dowex-50WX8-200 (220 mg, washed with methanol three times and dried under vacuum for $30 \mathrm{~min})$ in methanol $(14 \mathrm{~mL})$ containing 0.7 $\mathrm{mL} \mathrm{H}_{2} \mathrm{O}$. The mixture was stirred overnight at room temperature under an atmosphere of nitrogen. The solution was then filtered and the resin washed with methanol $(3 \times 5 \mathrm{~mL})$. The combined methanol layers were evaporated to afford a light yellow oil. Purification by flash chromatography with silica absorbent $\left(\mathrm{MeOH} / \mathrm{CH}_{2} \mathrm{Cl}_{2}, 1: 9\right)$ yielded $81 \mathrm{mg}(74 \%)$ of 9 as a white solid. mp 110-113 ${ }^{\circ} \mathrm{C} .{ }^{1} \mathrm{H}$ NMR (300 MHz, $\mathrm{CD}_{3} \mathrm{OD}$ ): $\delta 2.10$ (ddt, $J=17.4,3.9,1.5 \mathrm{~Hz}$, $1 \mathrm{H}), 2.60$ (ddt, $J=18.3,4.5,2.1 \mathrm{~Hz}, 1 \mathrm{H}), 3.64(\mathrm{~s}, 3 \mathrm{H}), 3.89$ (t, $J=5.1 \mathrm{~Hz}, 1 \mathrm{H}), 4.27$ (t, $J=1.8$ $\mathrm{Hz}, 1 \mathrm{H}), 4.50$ (br s, $1 \mathrm{H}), 6.69$ (pent, $J=1.8 \mathrm{~Hz}, 1 \mathrm{H}) .{ }^{13} \mathrm{C} \mathrm{NMR}\left(75 \mathrm{MHz}, \mathrm{CD}_{3} \mathrm{OD}\right): \delta 31.5$, $51.0,67.2,68.4,72.2(\mathrm{t}, J=22.5 \mathrm{~Hz}), 130.2,139.2,168.8$. $\mathrm{HRMS}^{-\mathrm{ESI}^{+}}[\mathrm{M}+\mathrm{Na}]^{+}$: calcd $\left(\mathrm{C}_{8} \mathrm{H}_{11} \mathrm{DNaO}_{5}\right)$ 212.0644; found 212.0643 .

\section{$\left[4-{ }^{2} \mathrm{H}\right]$ Chorismate (1e)}

This compound was prepared chemoenzymatically from compound $\mathbf{9}(40 \mathrm{mg}, 0.21 \mathrm{mmol})$ as described for [10- $\left.{ }^{12} \mathrm{C}\right]$ chorismic acid (1a). ${ }^{10}$ It was obtained as an off white solid (32 $\mathrm{mg}, 67$ \%). ${ }^{1} \mathrm{H}$ NMR (300 MHz, $\left.\mathrm{D}_{2} \mathrm{O}, \mathrm{pD} 6.0\right): \delta 4.45(\mathrm{~d}, J=2.7 \mathrm{~Hz}, 1 \mathrm{H}), 4.78(\mathrm{~d}, J=2.1 \mathrm{~Hz}, 1 \mathrm{H})$, $5.08(\mathrm{~d}, J=2.7 \mathrm{~Hz}, 1 \mathrm{H}), 5.83(\mathrm{~d}, J=10.8 \mathrm{~Hz}, 1 \mathrm{H}), 6.20(\mathrm{dd}, J=9.9,1.8 \mathrm{~Hz}, 1 \mathrm{H}), 6.43(\mathrm{~d}, J=$ $2.1 \mathrm{~Hz}, 1 \mathrm{H}) .{ }^{2} \mathrm{H}$ NMR $\left(61.4 \mathrm{MHz}, \mathrm{CH}_{3} \mathrm{OH}\right): \delta 4.61\left(\mathrm{br} \mathrm{s}, 1^{2} \mathrm{H}\right)$.

\section{Kinetic isotope effect measurements}

All manipulations were performed on ice to suppress the non-enzymatic decomposition of chorismate. Natural abundance chorismate or mixtures of specifically labeled substrates were dissolved in $50 \mathrm{mM}$ potassium phosphate buffer, $\mathrm{pH}$ 7.5. The chorismate concentration, determined spectroscopically at $274 \mathrm{~nm}\left(\Delta \varepsilon 2630 \mathrm{M}^{-1} \mathrm{~cm}^{-1}\right)$, was between 1 and $2 \mathrm{mM}$ for complete conversion reactions and between 4 and $6 \mathrm{mM}$ for partial conversion reactions. The substrate solution $(4 \mathrm{~mL})$ was placed in a sidearm decarboxylation flask fitted with a stopcock adapter. The solutions were sparged with moist $\mathrm{CO}_{2}$-free nitrogen gas. For the enzymatic reactions, the sample was warmed to $22{ }^{\circ} \mathrm{C}$ and an appropriate amount of chorismate mutase ( 0.25 Units) was introduced through the sidearm. Aliquots of the reaction mixture were removed and the progress of the reaction was monitored spectroscopically at $274 \mathrm{~nm}(\Delta \varepsilon 2630$ $\mathrm{M}^{-1} \mathrm{~cm}^{-1}$ ). At the desired endpoint (ca. $50 \%$ or $100 \%$ conversion), the reaction was quenched by addition of $300 \mu \mathrm{L}$ of $5 \mathrm{~N} \mathrm{HCl}$. After $45 \mathrm{~min}$ at room temperature, volatile products were collected under reduced pressure, using two liquid nitrogen/pentane traps $\left(-115^{\circ} \mathrm{C}\right)$ to remove contaminants and $\mathrm{H}_{2} \mathrm{O}$ and a liquid nitrogen trap $\left(-196{ }^{\circ} \mathrm{C}\right)$ to trap $\mathrm{CO}_{2}$. The ${ }^{13} \mathrm{CO}_{2} /{ }^{12} \mathrm{CO}_{2}$ ratio of the sample $\left(\mathrm{R}_{\mathrm{P}}\right)$ was then determined on a Finnigan delta $\mathrm{E}$ isotope ratio mass spectrometer as previously described. ${ }^{9}$ The remaining reaction solution from partial conversion experiments was subsequently treated with $\mathrm{KOH}$ to bring the $\mathrm{pH}$ to 6.5 and sparged with moist $\mathrm{CO}_{2}$-free nitrogen gas. Residual substrate was then completely converted to product by addition of wild-type $\mathrm{BsCM}$. After $12 \mathrm{~h}$ at $22^{\circ} \mathrm{C}, 5 \mathrm{~N} \mathrm{HCl}$ was added and the decarboxylation reaction was allowed to proceed for $45 \mathrm{~min}$. The $\mathrm{CO}_{2}$ was distilled at reduced pressure as described above and the ${ }^{13} \mathrm{CO}_{2} /{ }^{12} \mathrm{CO}_{2}$ ratio of the residual substrate $\left(\mathrm{R}_{\mathrm{S}}\right)$ was determined by mass spectrometry. All reactions were performed in triplicate. 
For the non-enzymatic reactions, $4 \mathrm{~mL}$ chorismate samples ( 2 to $4 \mathrm{mM}$ ) were incubated at 60 ${ }^{\circ} \mathrm{C}$ in the same buffer as that used in the enzyme-catalyzed reactions. The progress of the reaction was monitored by ${ }^{1} \mathrm{H}-\mathrm{NMR}$ and UV-vis spectroscopy. After 30 min, corresponding to conversion of ca. $50 \%$ of the starting material, the reaction was quenched with $5 \mathrm{~N} \mathrm{HCl}$ and the ${ }^{13} \mathrm{CO}_{2} /{ }^{12} \mathrm{CO}_{2}$ ratios, $R_{\mathrm{P}}$ and $R_{\mathrm{S}}$, were determined as described above. The $\mathrm{R}_{0}$ value for the samples, corresponding to the ${ }^{13} \mathrm{CO}_{2} /{ }^{12} \mathrm{CO}_{2}$ ratio obtained upon $100 \%$ conversion of chorismate, was obtained by adding wild-type BsCM as described above.

\section{NMR Kinetics}

The reaction of chorismate and $\left[{ }^{2} \mathrm{H}-4\right]$ chorismate $(20 \mathrm{mM})$ was monitored at $60{ }^{\circ} \mathrm{C}$ by ${ }^{1} \mathrm{H}$ NMR spectroscopy in deuterated phosphate buffer $(200 \mathrm{mM}, \mathrm{pD} 7.5)$ containing dioxane (1.0 $\mathrm{mM})$ as an internal standard. The concentrations of chorismate, prephenate, phenylpyruvate and 4-hydroxybenzoate were determined periodically by integration of representative, wellresolved peaks and comparison to the internal standard. The kinetic data were analyzed with the program DynaFit. ${ }^{17}$ The decomposition of $\left[{ }^{2} \mathrm{H}-4\right]$ chorismate in phosphate buffer ( $\mathrm{pH} 6.0$, $60{ }^{\circ} \mathrm{C}$ ) was similarly monitored by ${ }^{2} \mathrm{H}-\mathrm{NMR}$ spectroscopy using dioxane- $d 8$ as the internal standard. All experiments were performed in duplicate.

\section{Computational Studies}

All calculations were performed using the G03 series of programs 18 at the B3LYP/6-31+G* level of theory. Transition structures were characterized by harmonic frequency calculations and had exactly one negative eigenvalue, corresponding to the reaction coordinate, as confirmed by intrinsic reaction coordinate(IRC) calculations. Isotope effects were calculated using QUIVER ${ }^{19}$ and the harmonic frequencies, scaled by 0.961 , at temperatures of 295.15 $\mathrm{K}$ and $333.15 \mathrm{~K}$ and are corrected for tunneling with a one-dimensional tunneling approximates as proposed by Bell. 19, 20 An extended, diequatorial conformation of chorismate served as the reference state for the isotope effect calculations (see supplementary material).

\section{RESULTS}

\section{Labeled chorismates}

Primary heavy atom isotope effects on both the enzymatic and the non-enzymatic rearrangement of chorismate to prephenate were determined by the remote label method, 21 exploiting the $\mathrm{C} 10$ carboxylate of chorismate as the indicator position (Scheme 2). Prephenate decarboxylates quantitatively under acidic conditions, ${ }^{22}$ releasing the carbon at the indicator position as $\mathrm{CO}_{2}$. The isotopic composition of the latter was determined by isotope ratio mass spectrometry, enabling determination of isotope effects at the mechanistically interesting key positions $\mathrm{O} 7, \mathrm{C} 1$ and $\mathrm{C} 9$.

A ca. $99: 1$ mixture of $\left[10-{ }^{12} \mathrm{C}\right]$ chorismate $(\mathbf{1 a})$ and $\left[7_{-}{ }^{18} \mathrm{O}, 10-{ }^{13} \mathrm{C}\right]$ chorismate $(\mathbf{1 b})$ was used to determine a primary isotope effect at the site of bond breaking, whereas ca. 99:1 mixtures of $\left[10-{ }^{12} \mathrm{C}\right]$ chorismate $(\mathbf{1 a})$ and $\left[1,10-{ }^{13} \mathrm{C}\right]$ chorismate $(\mathbf{1 c})$ or $\left[9,10-{ }^{13} \mathrm{C}\right]$ chorismate $(\mathbf{1 d})$ were used to determine the isotope effects at the sites of bond formation. The required chorismate derivatives were prepared chemoenzymatically. Biosynthetic transformation of mixtures of singly and doubly labeled shikimates gave the $\mathbf{1 a} / \mathbf{1} \mathbf{b}$ and $\mathbf{1 a} / \mathbf{1 c}$ mixtures, as previously described. ${ }^{10}$ In contrast, the $\mathbf{1 a} / \mathbf{1 d}$ mixture was prepared by mixing independently synthesized 1a and 1d in the desired ratio. The latter mixture was treated with acid prior to enzymatic reaction to decompose contaminating prephenate originating from either of the components, which could serve as a source of $\mathrm{CO}_{2}$ and skew the isotopic ratios. 


\section{Enzymatic Reactions}

For determination of the isotope effects on the enzymatic reaction, unlabeled chorismate containing only natural abundance ${ }^{13} \mathrm{C}$ and the $\mathbf{1 a} / \mathbf{1 b}, \mathbf{1 a} / \mathbf{1} \mathbf{c}$ and $\mathbf{1 a} / \mathbf{1 d}$ substrate mixtures were converted enzymatically to prephenate in separate experiments. In each case, three complete conversion reactions were performed with 4 to $6 \mathrm{mM}$ chorismate with wild-type $\mathrm{BsCM}$, and three partial conversion reactions (to ca. 50\%) were carried out for the wild-type enzyme, the C75S BsCM variant, and EcCM. At the desired endpoint, the reaction was quenched with 5 $\mathrm{M} \mathrm{HCl}$ and volatile products were collected under reduced pressure, using two pentane/liquid $\mathrm{N}_{2}$ traps at $-115^{\circ} \mathrm{C}$ to remove $\mathrm{H}_{2} \mathrm{O}$ and other contaminants and a liquid $\mathrm{N}_{2}$ trap at $-196^{\circ} \mathrm{C}$ totrap $\mathrm{CO}_{2}$. The ${ }^{13} \mathrm{CO}_{2} /{ }^{12} \mathrm{CO}_{2}$ ratio of the sample was then determined on a Finnigan delta $\mathrm{E}$ isotope ratio mass spectrometer, and the heavy atom isotope effects were calculated according to eq.1:

$$
\mathrm{KIE}=\frac{\log (1-f)}{\log \left[1-f\left(R_{\mathrm{p}} / R_{0}\right)\right]}
$$

where $R_{0}$ is the isotope ratio of the remote label in the starting material (obtained by running the reaction to completion), $R_{\mathrm{P}}$ is the isotope ratio of the remote label in the product, and $f$ is the fractional conversion of substrate to product. The observed values for the $\mathbf{1 a} / \mathbf{1 b}, \mathbf{1 a} / \mathbf{1 c}$ and $\mathbf{1 a} / \mathbf{1 d}$ mixtures were divided by the secondary kinetic isotope effect at $\mathrm{C} 10$, measured with unlabeled chorismate to give the desired ${ }^{18} \mathrm{O}$ and ${ }^{13} \mathrm{C}$ isotope effects.

Data for the BsCM variants are summarized in Table 1, together with theoretical isotope effects based on the transition structure for the concerted reaction obtained at the Becke3LYP/6-31 $+\mathrm{G}^{*}$ level of theory. As previously reported, ${ }^{9}$ a very large ${ }^{18} \mathrm{O}$ effect on $\mathrm{C}-\mathrm{O}$ cleavage and a smaller, but still significant, ${ }^{13} \mathrm{C}$ effect at $\mathrm{C} 1$ are observed for the $\mathrm{BsCM}$-catalyzed reactions. The $1.3 \%$ and $1.1 \%{ }^{13} \mathrm{C}$ effects at $\mathrm{C} 9$ for the $\mathrm{BsCM}$ and $\mathrm{C} 75 \mathrm{~S}$ BsCM variants, respectively, confirm that $\mathrm{C}-\mathrm{C}$ bond formation lags considerably behind $\mathrm{C}-\mathrm{O}$ bond formation in the enzyme-catalyzed reaction. Data for the structurally unrelated helical bundle mutase EcCM, which are also reported in Table 1, are qualitatively similar to those obtained with BsCM. The $4.6 \%{ }^{18} \mathrm{O} \mathrm{KIE}$ at $\mathrm{O} 7$ and the smaller $1.5 \%{ }^{13} \mathrm{C} \mathrm{KIE}$ at $\mathrm{C} 1$ closely match the corresponding theoretical isotope effects.

\section{Non-Enzymatic Reactions}

Chorismate decomposes with a $t_{1 / 2}$ of $\sim 30 \mathrm{~min}$ at $60{ }^{\circ} \mathrm{C}$. ${ }^{4}$ Under these conditions, elimination of the enolpyruvyl side chain to give 4-hydroxybenzoate competes with the Claisen rearrangement to prephenate, and prephenate is converted to phenylpyruvate, as summarized in Scheme 3. ${ }^{4}$

The thermal reaction can be directly monitored by ${ }^{1} \mathrm{H}$ NMR spectroscopy. A typical time course for the decomposition of unlabeled chorismate at $60^{\circ} \mathrm{C}$ in $200 \mathrm{mM}$ sodium phosphate buffer in $\mathrm{D}_{2} \mathrm{O}(\mathrm{pD} 7.5)$ is shown in Figure 1A. The rate constants obtained are $k_{1}=(2.98 \pm 0.01) \times$ $10^{-4} \mathrm{~s}^{-1}, k_{2}=(2.59 \pm 0.05) \times 10^{-5} \mathrm{~s}^{-1}$, and $k_{3}=(3.26 \pm 0.09) \times 10^{-5} \mathrm{~s}^{-1}$. Although a $k_{1} / k_{3}$ ratio of ca. 4 was previously reported based on indirect measurements of the reaction constituents, 4 we find a value of 9:1. Under the conditions of our experiment, the pyruvate that is produced in the elimination step also exchanges with solvent with an apparent rate constant of $k_{4}=(6.8$ $\pm 0.6) \times 10^{-4} \mathrm{~s}^{-1}$.

Heavy atom isotope effects on the non-enzymatic Claisen rearrangement to give prephenate, ${ }^{18} k_{1}$ and ${ }^{13} k_{1}$, were determined at $60{ }^{\circ} \mathrm{C}$ as described for the enzymatic reactions and calculated from the following relationship:

$$
{ }^{\mathrm{x}} k_{1}=\left(\frac{\log (1-f)}{\log \left[(1-f)\left(R_{\mathrm{S}} / R_{0}\right)\right]}\right)\left(\frac{\left[1-(1-f)\left(R_{\mathrm{S}} / R_{0}\right)\right]}{\left[f\left(R_{\mathrm{p}} / R_{0}\right)\right]}\right)
$$


where ${ }^{\mathrm{x}} k_{1}$ is the apparent isotope effect, expressed as a ratio of the rate constants for the light and heavy (x) isotopes. A derivation of eq. 2 is provided in the Supplementary Material. The ${ }^{18} \mathrm{O}$ isotope effect at $\mathrm{O} 7$ and the ${ }^{13} \mathrm{C}$ effect at $\mathrm{C} 1$ (Table 2) are in excellent agreement with the theoretical isotope effects (Table 1).

Because only small amounts of hydroxybenzoic acid are formed in the thermal reaction, it was not possible to determine the heavy atom isotope effects, ${ }^{18} k$ and ${ }^{13} 3 k_{3}$, on the elimination reaction directly. However, these KIEs were estimated according to eq. 3 (for a derivation, see Supplementary Material):

$$
{ }^{\mathrm{x}} k_{3}=\frac{{ }^{\mathrm{x}} k_{1}}{\left(1+k_{1} / k_{3}\right) / \alpha-k_{1} / k_{3}}
$$

where ${ }^{\mathrm{x}} \mathrm{k}_{1}$ is the isotope effect value obtained from eq. $2, \mathrm{k}_{1}$ and $\mathrm{k}_{3}$ are the rate constants for the formation of prephenate and 4-hydroxybenzoate estimated from the product distribution ratios, and $\alpha=\left[f\left(R_{\mathrm{P}} / R_{0}\right)\right] /\left[1-(1-f)\left(R_{\mathrm{S}} / R_{0}\right)\right]$. The values are summarized in Table $2 .{ }^{23}$ The $3.74 \%{ }^{18} \mathrm{O}$ isotope effect indicates extensive $\mathrm{C}-\mathrm{O}$ bond cleavage in the transition state for the elimination. The $1.13 \%{ }^{13} \mathrm{C}$ isotope effect at $\mathrm{C} 1$ reflects the decrease in bond order associated with the increase in positive charge at this site.

To gain further insight into the competing elimination reaction, $\left[4{ }^{2} \mathrm{H}\right]$ chorismate (1e) was prepared chemoenzymatically according to Scheme 4. Its decomposition was monitored at 60 ${ }^{\circ} \mathrm{C}$ in $200 \mathrm{mM}$ sodium phosphate buffer in $\mathrm{D}_{2} \mathrm{O}$ (pD 7.5) by ${ }^{1} \mathrm{H}$ NMR spectroscopy as shown in Figure 1B. The rate constants obtained are $k_{1}=(2.78 \pm 0.10) \times 10^{-4} \mathrm{~s}^{-1}, k_{2}=(2.19 \pm 0.04) \times$ $10^{-5} \mathrm{~s}^{-1}$, and $k_{3}=(1.77 \pm 0.03) \times 10^{-5} \mathrm{~s}-1$, affording deuterium isotope effects of $1.07 \pm 0.04$, $1.19 \pm 0.03$ and $1.85 \pm 0.06$ on the $k_{1}, k_{2}$ and $k_{3}$ steps, respectively. Based on the value of ${ }^{\mathrm{D}} k_{3}, \mathrm{C}$ $-\mathrm{H}$ bond cleavage is not far advanced in the transition state for the elimination. The fate of the deuterium atom at $\mathrm{C} 4$ in this pathway was determined by ${ }^{2} \mathrm{H}$ NMR spectroscopy at $60{ }^{\circ} \mathrm{C}$ and $\mathrm{pH} 6.0$ (to minimize exchange with solvent). In addition to $\left[4-{ }^{2} \mathrm{H}\right]$ phenylpyruvate,

formation of $\left[3-{ }^{2} \mathrm{H}\right]$ pyruvate was directly observed (Figure 2 ). Based on the ratio of integrated signals for pyruvate to 4-hydroxybenzoate observed by ${ }^{1} \mathrm{H}-\mathrm{NMR}$ spectroscopy after lyophilization of the sample, $62 \%$ of the pyruvate formed after 3 hours contains deuterium originating from $\mathrm{C} 4$ of the labeled chorismate.

${ }^{\text {a }}$ Conditions: (a) $\left(\mathrm{CF}_{3} \mathrm{SO}_{2}\right)_{2} \mathrm{O}$, py, $\mathrm{CH}_{2} \mathrm{Cl}_{2},-30{ }^{\circ} \mathrm{C}$; (b) $(\mathrm{EtO})_{2} \mathrm{P}(\mathrm{O}) \mathrm{CH}_{2} \mathrm{CO}_{2} \mathrm{Me}, \mathrm{NaH}$, DMF, $83 \%$ over two steps; (c) $\mathrm{Pd} / \mathrm{C}, \mathrm{MeOH}, \mathrm{HCO}_{2} \mathrm{NH}_{4}, 50{ }^{\circ} \mathrm{C}, 94 \%$; (d) $\mathrm{P}_{2} \mathrm{O}_{5}$, DMSO, DMF, $70^{\circ}$ $\mathrm{C}$; (e) $\mathrm{NaBD}_{4}, \mathrm{MeOH}, 0{ }^{\circ} \mathrm{C}, 85 \%$ over two steps; (f) Dowex-50w, acetone, $88 \%$; (g) MeOH, $\mathrm{Na}^{0}, 0^{\circ} \mathrm{C}, 27 \%$; (h) Dowex-50w, $\mathrm{MeOH} / \mathrm{H}_{2} \mathrm{O}, 74 \%$; (i) $\mathrm{NaOH}$, THF, $\mathrm{H}_{2} \mathrm{O}$; (j) KA12/pKAD50, Tris-HCl, PEP, ATP, FMN, KCl, $\mathrm{MgSO}_{4}, \mathrm{NaS}_{2} \mathrm{O}_{4}, 67 \%$ over two steps.

\section{DISCUSSION}

Aliphatic and aromatic Claisen rearrangements have been extensively investigated by theory 24 and experiment. 25,26 High-level calculations indicate that these reactions are concerted and proceed via cyclically delocalized, chair-like transition states in which carbon-oxygen bond cleavage precedes carbon-carbon bond formation. Experimental ${ }^{13} \mathrm{C}$ and ${ }^{2} \mathrm{H}$ isotope effects have been determined by multisite NMR methods for the archetypal rearrangement of allyl vinyl ether and allyl phenyl ether which exhibit excellent quantitative agreement with calculated isotope effects. 27 These findings provide confidence in the ability of theory to account for the multidimensional bonding changes that occur along the reaction coordinate.

For the chorismate-to-prephenate transformation, density functional theory (DFT) calculations in vacuo predict a somewhat looser aromatic transition state than the canonical aliphatic Claisen rearrangement, with bond lengths of $2.127 \AA$ and $2.660 \AA$ for the breaking $\mathrm{C}-\mathrm{O}$ and forming 
C-C bonds, respectively (Figure 3). 9,28 In qualitative agreement with this model, secondary tritium isotope effects on the thermal reaction indicated significant cleavage of the $\mathrm{C}-\mathrm{O}$ bond (ca. $40 \%$ ) but little or no formation of the $\mathrm{C}-\mathrm{C}$ bond. ${ }^{1}$ The heavy atom isotope effects determined in the current study confirm and extend this picture. The very large ${ }^{18} \mathrm{O}$ effect at $\mathrm{O} 7$, the site of bond breaking, and the smaller, but still significant ${ }^{13} \mathrm{C}$ effect at $\mathrm{C} 1$, the site of bond making, are both in excellent accord with the kinetic isotope effects calculated at the Becke3LYP/6-31+G* level of theory for a pericyclic transition state (Table 1). This picture is rounded out by the observation of a small secondary ${ }^{2} \mathrm{H}$ effect for the hydrogen at $\mathrm{C} 4$, consistent with hyperconjugative stabilization of the developing positive charge on the ring. In this case, the agreement between theory and experiment is less good (observed, $1.07 ; 0.04$; predicted 0.87), presumably due to the fact that the dihedral angle between the hydrogen at $\mathrm{C} 4$ and the cyclohexadienyl ring is not predicted accurately; even relatively small changes in the predicted angle will influence the extent of hyperconjugation, leading to significant uncertainty in the predicted isotope effect at this position. Together, the data provide strong experimental evidence that the thermalrearrangement is a concerted, albeit asynchronous, [3,3]-sigmatropic process. 29

In principle, chorismate mutases, which accelerate this transformation more than a millionfold, could lower the energy barrier for rearrangement simply by stabilizing the pericyclic transition state observed in solution. Alternatively, the enzymes might perturb this structure or even favor alternative mechanisms, such as a two-step dissociative pathway or other routes. ${ }^{30}$ The observation of a large ${ }^{18} \mathrm{O}$ effect at $\mathrm{O} 7$, and a smaller ${ }^{13} \mathrm{C}$ effect at $\mathrm{C} 1$ for the reaction catalyzed by the AroH mutase from $B$. subtilis had previously been used to argue that the enzymatic reaction, like its solution counterpart, is a concerted pericyclic process with some $\mathrm{C}-\mathrm{C}$ bond formation accompanying $\mathrm{C}-\mathrm{O}$ bond cleavage. ${ }^{9}$ The ${ }^{13} \mathrm{C}$ isotope effect of $1.0129 \pm 0.0024$ at C9 of chorismate with wild type BsCM, which was determined in the current study, strengthens this conclusion. A stepwise mechanism should be insensitive to isotopic substitution at C9, because the ion pair intermediate would be expected to partition preferentially forward to give prephenate, rather than revert to chorismate. ${ }^{29}$ The significant isotope effects observed at both $\mathrm{C} 1$ and $\mathrm{C} 9$ - both ends of the reacting $\pi$ system - strengthen the conclusion that the $\mathrm{C}-\mathrm{C}$ bond is partially formed in the transition state.

Significant slowing of the BsCM-catalyzed reaction by viscosogens like glycerol points to the chemical step being only partially rate determining in this system. ${ }^{13}$ As a consequence, the intrinsic isotope effects may not be fully expressed. Consistent with this possibility, the sluggish C75S variant, which is insensitive to changes in microviscosity, ${ }^{13}$ exhibits a significantly larger ${ }^{18} \mathrm{O}$ isotope effect than $\mathrm{BsCM}$ itself or the theoretical prediction. 9 Moreover, the ${ }^{13} \mathrm{C}$ isotope effects at $\mathrm{C} 1$ and $\mathrm{C} 9$ are somewhat smaller than predicted by theory (Table 1). Together, these data imply that the enzymatic reaction may have a more dissociative transition state than the thermal process. Such a species could be stabilized by ionic groups that line the active site, ${ }^{7}$ including Arg90, which directly contributes a hydrogen bond to the ether oxygen of chorismate in the transition state. ${ }^{31}$ Hartree-Fock calculations support the ability of such interactions to alter the reactant and transition state electronically relative to their gas-phase counterparts, ${ }^{32}$ although the computed C5-O7 and C1-C9 distances for the enzyme-bound transition state are longer and shorter, respectively, than found experimentally. These discrepancies probably reflect a combination of experimental inaccuracy, chemical differences between the wild type and mutant enzymes, and computational limitations with such large systems.

$\mathrm{EcCM}$, the second enzyme examined in this study, is representative of the AroQ family of chorismate mutases. It is evolutionarily unrelated to $\mathrm{BsCM}$, but exhibits similar steady-state parameters 14,33 and has a comparably configured active site. ${ }^{6}$ In this case, the isotope effects closely match the predicted values(Tables 1), indicating that an ionic active site environment 
need not necessarily alter the structure of the Claisen transition state. However, this conclusion rests on the uncertain assumption that chemistry is fully rate determining in this system. Although viscosogens have no effect on EcCM activity, ${ }^{13}$ it is conceivable that a kinetically significant, but isotopically insensitive, conformational isomerization of bound chorismate precedes the actual rearrangement. This step might correspond to conversion of chorismate from its preferred pseudo-equatorial conformation to a pseudo-axial conformation in which the carboxyvinyloxy group is aligned for reaction. ${ }^{34}$ Such a scenario has been proposed to explain why isotope effects on the reaction catalyzed by the related $E$. coli chorismate mutaseprephenate dehydrogenase are suppressed. ${ }^{1}$

In the absence of enzyme, conversion of chorismate to 4-hydroxybenzoate and pyruvate competes with the Claisen rearrangement leading to prephenate. ${ }^{4}$ As in the transformation of 3-(methoxycarbonyl)-5-ethenoxycyclohexadiene-cis-6-d to give methyl benzoate and $\mathrm{CH}_{2} \mathrm{DCHO},{ }^{26}$ this side reaction occurs via a concerted pericyclic mechanism in which C9 removes a proton (deuteron) from $\mathrm{C} 4$ rather than adding to $\mathrm{C} 1$ (Scheme 5). Substantial transfer of deuterium from $\mathrm{C} 4$ of chorismate to pyruvate is observed, arguing against the involvement of an external base. The small amount of label lost to solvent (ca. $40 \%$ after $3 \mathrm{~h}$ reaction) is readily explained by exchange under the experimental conditions. The ${ }^{2} \mathrm{H}$ isotope effect on the elimination (1.85 \pm 0.06$)$ is similar in magnitude to that observed for 3-(methoxycarbonyl)-5ethenoxycyclohexadiene-cis-6-d. In addition, like the Claisen rearrangement, elimination of the enolpyruvyl group is subject to a large ${ }^{18} \mathrm{O}$ isotope effect at $\mathrm{O} 7(1.0374 \pm 0.0005)$. These results show that the $\mathrm{C}-\mathrm{O}$ bond is substantially cleaved in the transition state but that transfer of the hydrogen from $\mathrm{C} 4$ to $\mathrm{C} 9$ is not far advanced, in qualitative agreement with theoretical calculations (Figure 4, Table 2). ${ }^{23}$ Both reactions, elimination and rearrangement, thus appear to be concerted but highly asynchronous.

Although the elimination is a minor side reaction thermally, the enzyme chorismate pyruvatelyase efficiently converts chorismate to 4-hydroxybenzoate for the ubiquinone biosynthetic pathway. ${ }^{35}$ Our results suggest that the latter enzyme and the related isochorismate pyruvatelyase, which converts isochorismate to salicylate for the biosynthesis of many siderophores, 36 might operate by otherwise rare pericyclic mechanisms.

In summary, competitive experiments with isotopically labeled chorismate derivatives have provided direct information about the nature of the transition state of the chorismate mutase reaction both in solution and at the active sites of evolutionarily unrelated enzymes. In all cases, the reaction proceeds via a pericyclic transition state in which $\mathrm{C}-\mathrm{C}$ bond formation lags considerably behind $\mathrm{C}-\mathrm{O}$ bond cleavage. Excellent quantitative agreement between theory and experiment is found for the uncatalyzed reaction, whereas the ionic active site of the enzymes may polarize the transition state somewhat compared to its solution counterpart. The competing reaction of chorismate leading to 4-hydroxybenzoate, an intermediate in ubiquinone biosynthesis, likewise appears to occur via an asynchronous concerted mechanism. The latter finding raises the intriguing possibility that additional protein catalysts promoting pericyclic processes will be found.

\section{Supplementary Material}

Refer to Web version on PubMed Central for supplementary material.

\section{Acknowledgment}

This work was supported by NIH Grant GM 18938 to W.W.C., NIH Grant GM 20571 to S.K.W., NSF grant DMR0079647 to O.W., and the Schweizer Nationalfonds to D.H. We are grateful to Prof. J. Frost for his gift of plasmid pKAD50 and to Prof. D. Singleton for helpful discussions. 


\section{References}

1. Addadi L, Jaffe EK, Knowles JR. Biochemistry 1983;22:4494-4501. [PubMed: 6354259]

2. Sogo SG, Widlanski TS, Hoare JH, Grimshaw CE, Berchtold GA, Knowles JR. J. Am. Chem. Soc 1984;106:2701-2703.

3. Wiest O, Houk KN. J. Am. Chem. Soc 1995;117:11628-11639.Wiest O, Houk KN. J. Org. Chem 1994;59:7582-7584.

4. Andrews PR, Smith GD, Young IG. Biochemistry 1973;12:3492-3498. [PubMed: 4731190]

5. Lee AY, Stewart JD, Clardy J, Ganem B. Chem. Biol 1995;2:195-203. [PubMed: 9383421]

6. Lee AY, Karplus PA, Ganem B, Clardy J. J. Am. Chem. Soc 1995;117:3627-3628.

7. Chook YM, Gray JV, Ke HM, Lipscomb WN. J. Mol. Biol 1994;240:476-500. [PubMed: 8046752]

8. Chook YM, Ke HM, Lipscomb WN. Proc. Natl. Acad. Sci. U.S.A 1993;90:8600-8603. [PubMed: 8378335]

9. Gustin DJ, Mattei P, Kast P, Wiest O, Lee L, Cleland WW, Hilvert D. J. Am. Chem. Soc 1999;121:1756-1757.

10. Gustin DJ, Hilvert D. J. Org. Chem 1999;64:4935-4938. [PubMed: 11674574]

11. Hirschbein BL, Mazenod FP, Whitesides GM. J. Org. Chem 1982;47:3765-3766.

12. Grisostomi C, Kast P, Pulido R, Huynh J, Hilvert D. Bioorg. Chem 1997;25:297-305.

13. Mattei P, Kast P, Hilvert D. Eur. J. Biochem 1999;261:25-32. [PubMed: 10103029]

14. MacBeath G, Kast P, Hilvert D. Biochemistry 1998;37:10062-10073. [PubMed: 9665711]

15. Kast P, AsifUllah M, Hilvert D. Tetrahedron Lett 1996;37:2691-2694.Dell KA, Frost JW. J. Am. Chem. Soc 1993;115:11581-11589.

16. Moore BS, Cho H, Casati R, Kennedy E, Reynolds KA, Mocek U, Beale JM. J. Am. Chem. Soc 1993;115:5254-5266.

17. Kuzmic P. Anal. Biochem 1996;237:260-273. [PubMed: 8660575]

18. Frisch, MJ. Gaussian03 Revision C.01. Wallingford, CT: 2004.

19. Saunders M, Laidig KE, Wolfsberg M. J. Am. Chem. Soc 1989;111:8989-8994.

20. Bell, RP. The Tunnel Effect in Chemistry. Chapman and Hall; New York: 1980. p. 60-63.

21. O'Leary MH. Methods Enzymol 1980;64:83-104. [PubMed: 6768960]

22. Zamir LO, Tiberio R, Jensen RA. Tetrahedron Lett 1983;24:2815-2818.

23. The agreement between theory and experiment is poorer for the heavy atom isotope effects on the elimination reaction than for the Claisen rearrangement, probably due to the indirect nature of the experimental determinations. The discrepancy in the case of the deuterium isotope effects can be attributed to the fact that the one-dimensional tunneling correction is insufficient. An explicit quantum mechanical treatment of the nuclear hydrogen coordinate is likely to be required, but is currently not possible for systems of this size.

24. Dewar MJS, Healy EF. J. Am. Chem. Soc 1984;106:7127.Vance RL, Rondan NG, Houk KN, Jensen F, Borden WT, Komornicki A, Wimmer E. J. Am. Chem. Soc 1988;110:2314-2315.Vance RL, Rondan NG, Houk KN, Jensen F, Borden WT, Komornicki A, Wimmer E. J. Am. Chem. Soc 1988;110:2314-2315.Dewar MJS, Jie C. J. Am. Chem. Soc 1989;111:511. Wiest O, Black KA, Houk KN. J. Am. Chem. Soc 1994;116:10336-10337.Davidson MM, Hillier IH, Vincent M. Chem. Phys. Lett 1995;246:536. Yamabe S, Okumoto S, Hayashi T. J. Org. Chem 1996;61:6218-6226. [PubMed: 11667458]

25. Ziegler FE. Chem. Rev 1988;88:1423.Gajewski JJ, Conrad ND. J. Am. Chem. Soc 1979;101:27472748.McMichael KD, Korver GL. J. Am. Chem. Soc 1979;101:2746-2747.Coates RM, Rogers BD, Hobbs SJ, Peck DR, Curran DP. J. Am. Chem. Soc 1987;109:1160-1170.Kupczyk-Subotkowska L, Saunders WH Jr. Shine HJ. J. Am. Chem. Soc 1988;110:7153-7159.Kupczyk-Subotkowska L, Subotkowski W, Saunders WH Jr. Shine HJ. J. Am.Chem. Soc 1992;114:3441-3445.KupczykSubotkowska L, Saunders WH Jr. Shine HJ, Subotkowski W. J. Am. Chem. Soc 1993;115:59575961.Gajewski JJ, Brichford NL. J. Am. Chem. Soc 1994;116:3165.Gajewski JJ. Acc. Chem. Res 1997;30:219-225.

26. Gajewski JJ, Jurayj J, Kimbrough DR, Gande ME, Ganem B, Carpenter BK. J. Am. Chem. Soc 1987;109:1170-1186. 
27. Meyer MP, DelMonte AJ, Singleton DA. J. Am. Chem. Soc 1999;121:10865-10874.

28. This structure has slightly shorter C-O and C-C bond lengths than the transition state reported previously (ref. 9), but the effect on the calculated heavy atom isotope effects is small. The relative looseness of the calculated transition state probably reflects electrostatic repulsion of the negatively charged carboxylate groups in the chair geometry, as well as the known bias of the B3LYP method (ref. 27).

29. An alternative two-step mechanism involving an ion pair intermediate was also considered. However, efforts to locate the transition structure for a fully dissociative process computationally inevitably led to transition structures for the concerted elimination pathway (Fig. 4). Moreover, such a mechanism would predict identical deuterium kinetic isotope effects on both the rearrangement and elimination processes, which are not observed experimentally (Table 2). Finally, the $>1 \%{ }^{13} \mathrm{C}$ isotope effect seen at C9 in the enzymatic reactions (Table 1) also argues against a stepwise mechanism, since the bond order to $\mathrm{C} 9$ is not expected to decrease substantially in such a process. Although the $\mathrm{C}-\mathrm{C}-\mathrm{O}-\mathrm{C}$ torsional mode would be lost in the enolate intermediate, this will not give a full $1 \%$ isotope effect.

30. Guilford WJ, Copley SD, Knowles JR. JACS 1987;109:5013-5019.

31. Kienhöfer A, Kast P, Hilvert D. J. Am. Chem. Soc 2003;125:3206-3207. [PubMed: 12630863]

32. Worthington SE, Roitberg AE, Krauss M. Intl. J. Quant. Chem 2003;94:287-292.

33. Stewart J, Wilson DB, Ganem B. J. Am. Chem. Soc 1990;112:4582-4584.

34. Copley SD, Knowles JR. J. Am. Chem. Soc 1987;109:5008-5013.

35. Siebert M, Severin K, Heide L. Microbiology-UK 1994;140:897-904.Holden MJ, Mayhew MP, Gallagher DT, Vilker VL. Biochim. Biophys. Acta-Protein Struct. Mol. Enzymol 2002;1594:160167.

36. Serino L, Reimmann C, Baur H, Beyeler M, Visca P, Haas D. Mol. Gen. Genet 1995;249:217-228. [PubMed: 7500944]Serino L, Reinmann C, Visca P, Beyeler M, Chiesa VD, Haas D. J. Bacteriol 1997;179:248-257. [PubMed: 8982005]Gaille C, Kast P, Haas D. J. Biol. Chem 2002;277:2176821775. [PubMed: 11937513] 


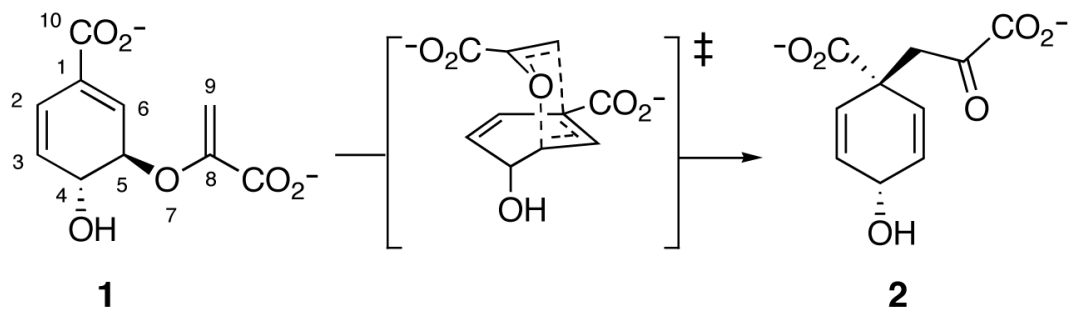

Scheme 1. 


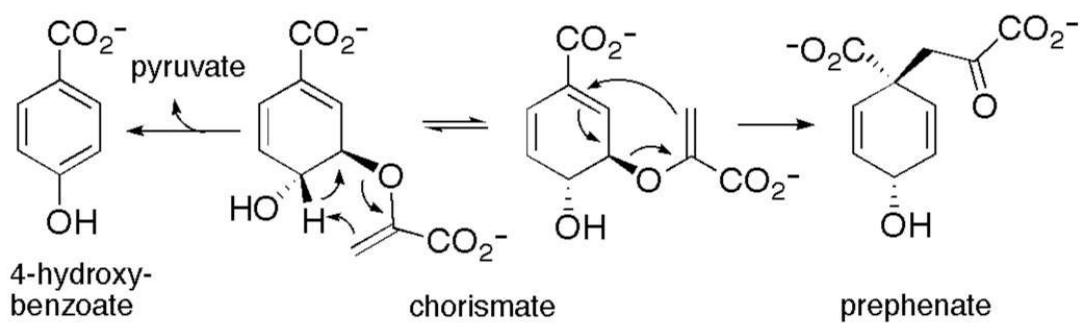

Scheme 2.

Isotopically labeled chorismate derivatives. 


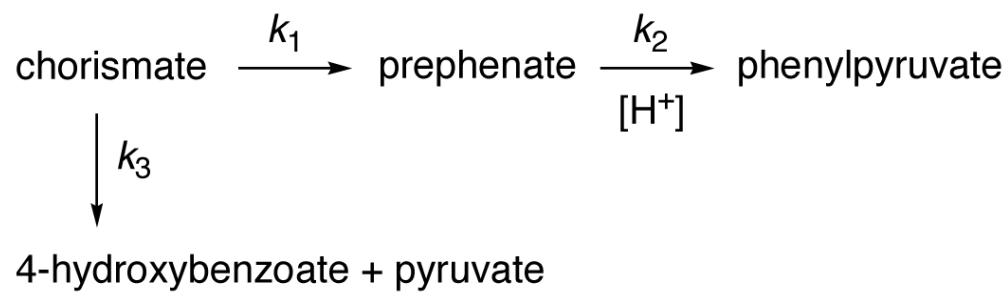

Scheme 3. 

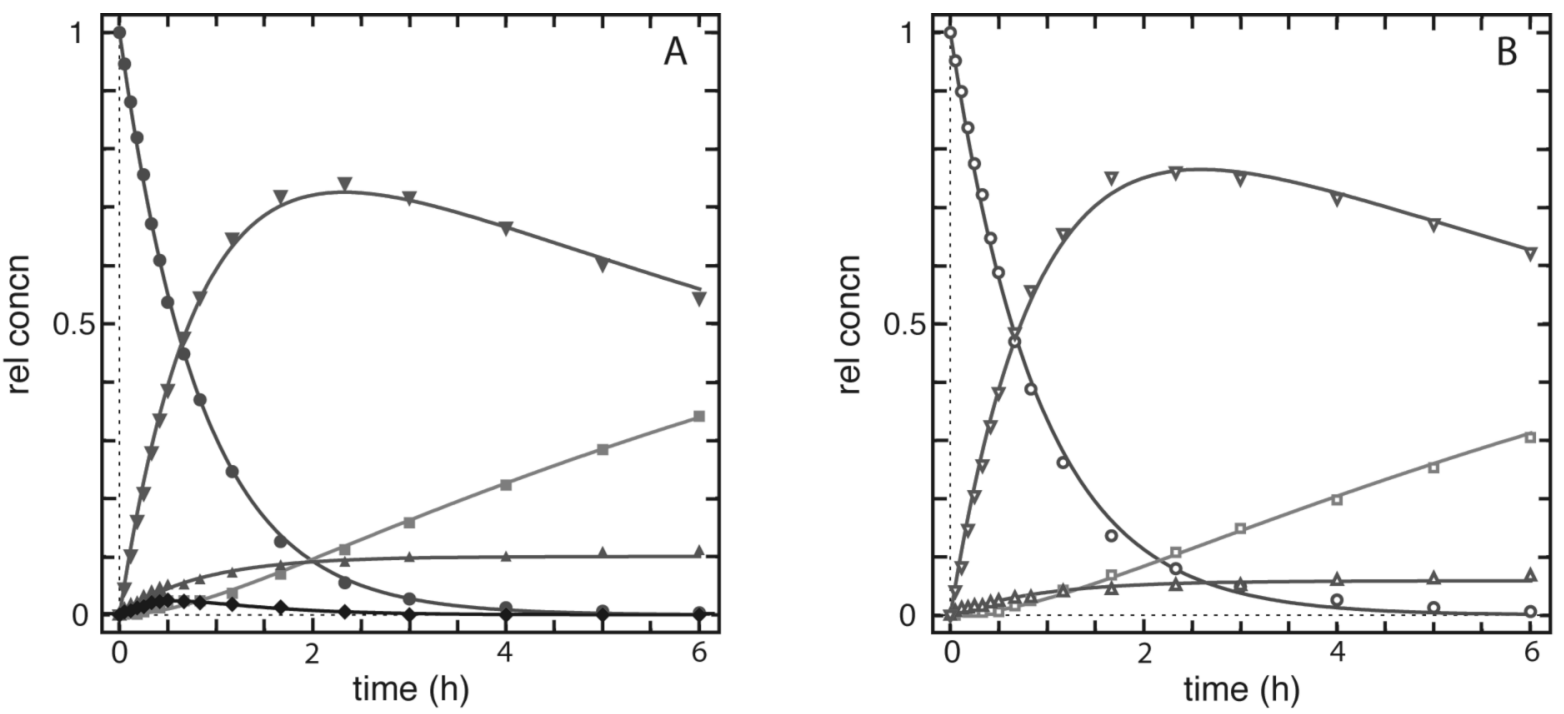

Figure 1.

Kinetic analysis of the non-enzymatic decomposition of chorismate $(\mathrm{A})$ and $\left[4-{ }^{2} \mathrm{H}\right]$ chorismate (B) in $200 \mathrm{mM}$ phosphate buffer in $\mathrm{D}_{2} \mathrm{O}$ at $60^{\circ} \mathrm{C}$. The reactions were monitored by ${ }^{1} \mathrm{H}$ NMR spectroscopy. Relative concentrations of chorismate (red, $\bullet$ ), prephenate (blue, $\boldsymbol{\nabla}$ ), phenylpyruvate (green, $\mathbf{\bullet})$, 4-hydroxybenzoate (magenta, $\mathbf{\Lambda}$ ) and pyruvate (black,, ) are plotted as a function of time. The data were analyzed with the program DynaFit. 17 

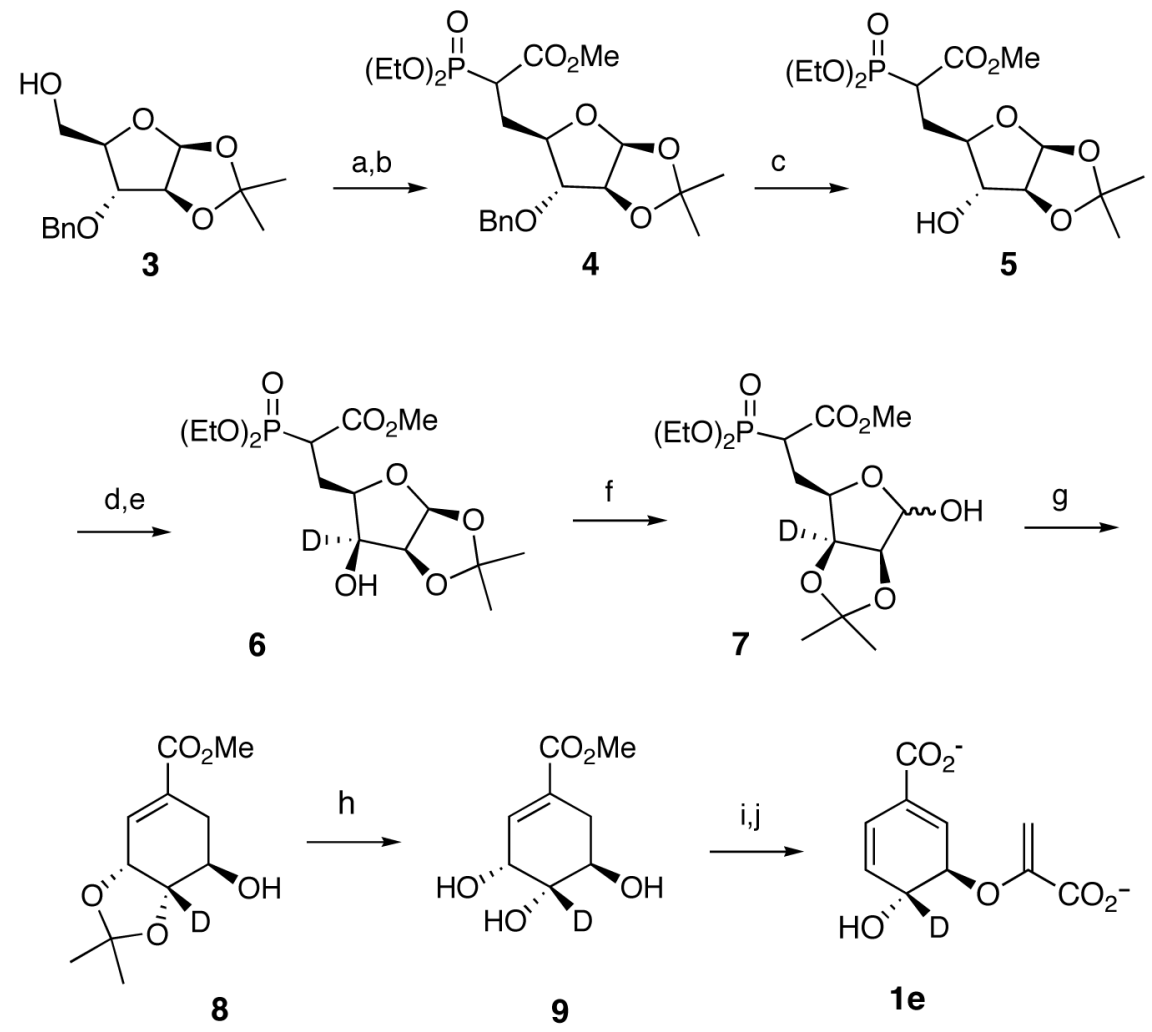

Scheme 4.

Synthesis of $\left[4-{ }^{2} \mathrm{H}\right]$ chorismate $(\mathbf{1 e})^{\mathrm{a}}$. 


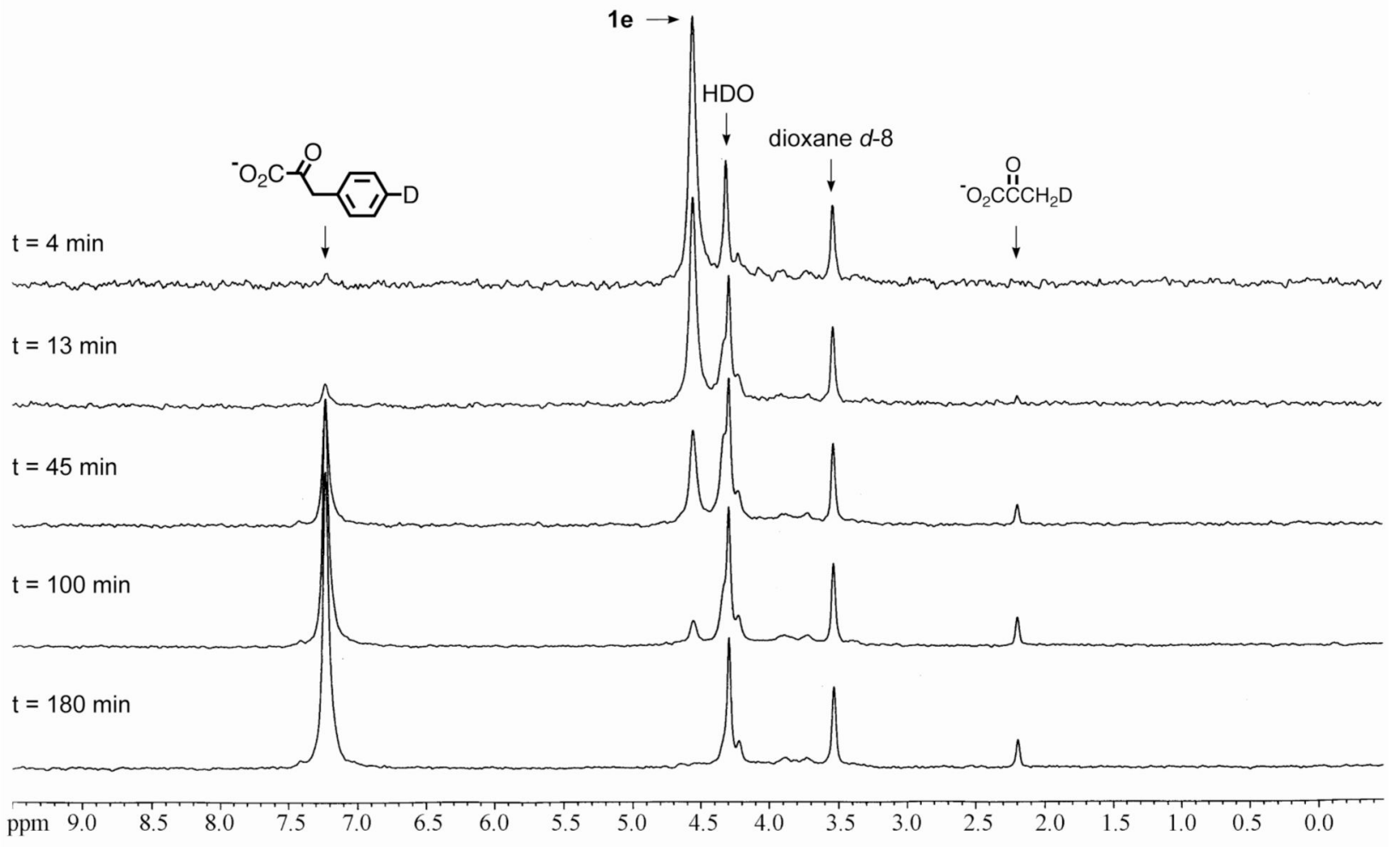

Figure 2.

Decomposition of $\left[4{ }^{2} \mathrm{H}\right]$ chorismate (1e) in $100 \mathrm{mM}$ phosphate buffer at $\mathrm{pH} 6.0$ and $60{ }^{\circ} \mathrm{C}$ monitored by ${ }^{2} \mathrm{H}-\mathrm{NMR}$ spectroscopy. 


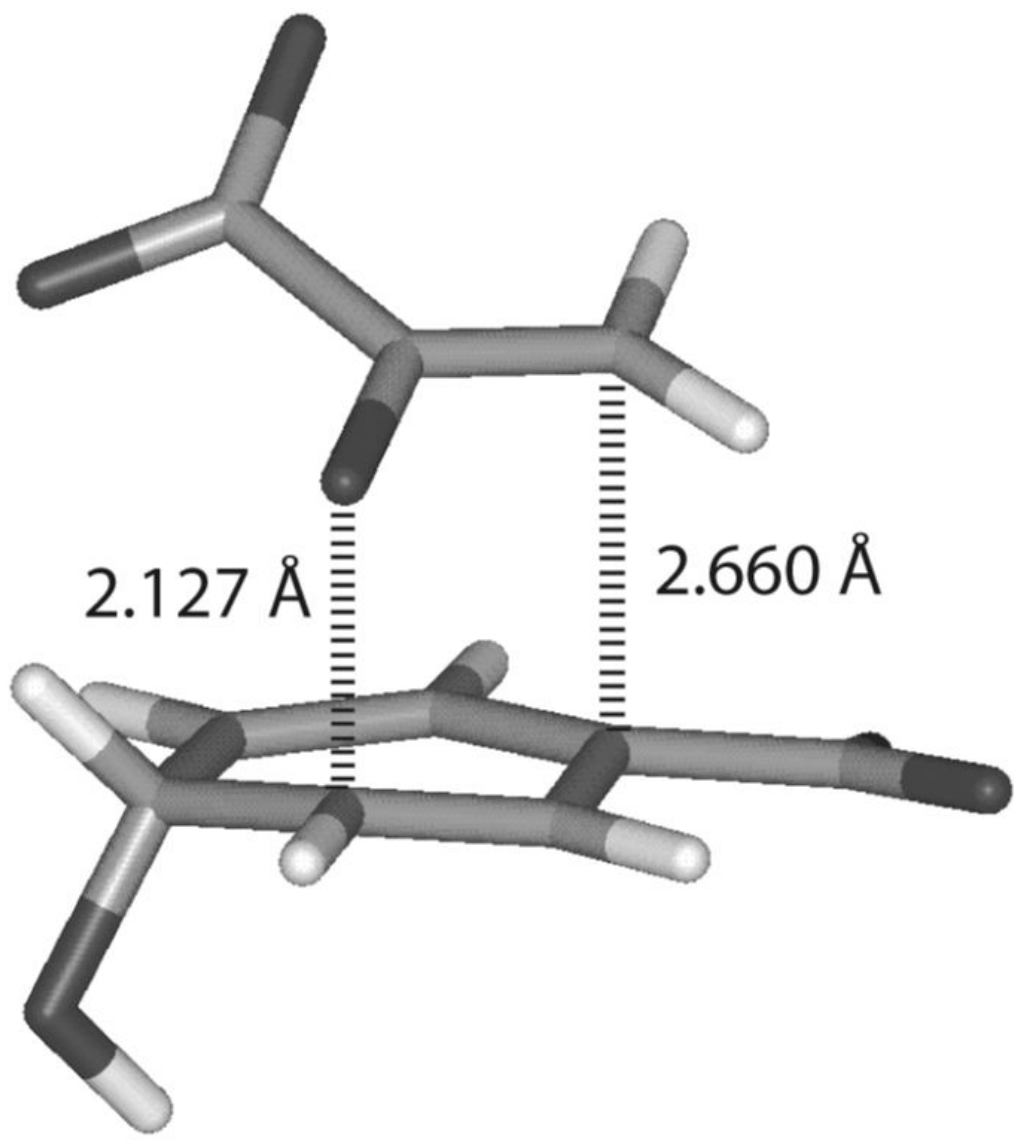

Figure 3.

Becke3LYP/6-31+G* transition structure for the Claisen rearrangement of chorismate. 


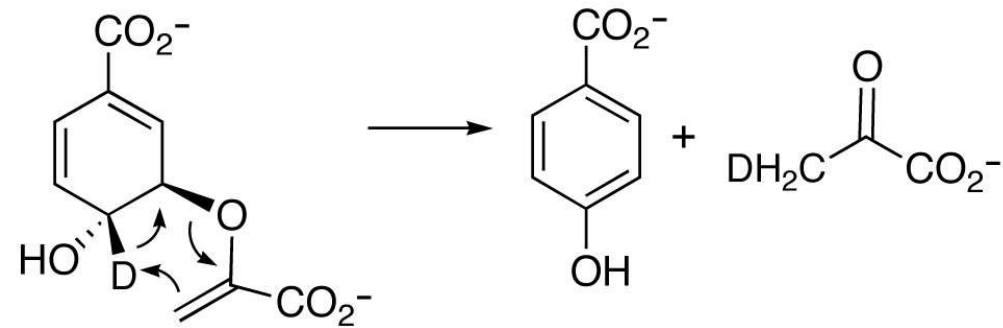

Scheme 5. 


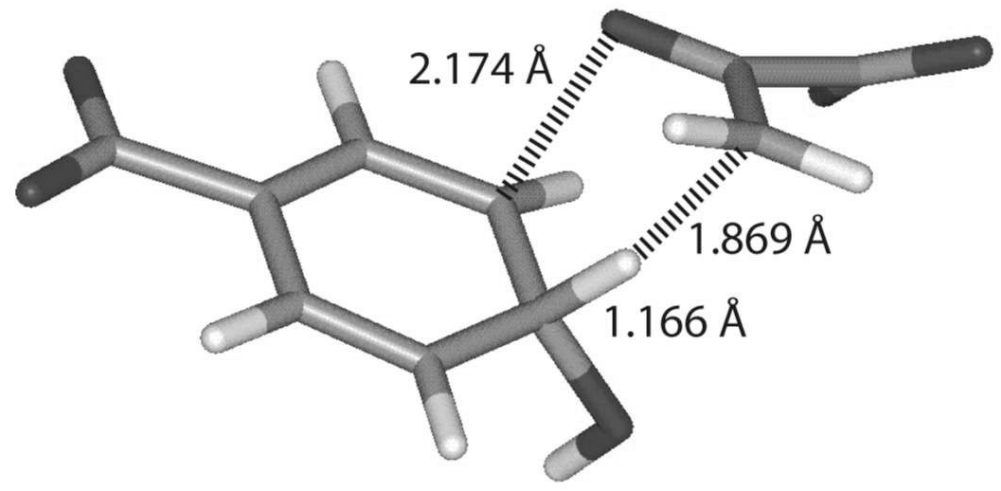

Figure 4.

Becke3LYP/6-31+G* transition structure for the conversion of chorismate to 4hydroxybenzoate. 
Table 1

Kinetic isotope effects for wild-type BsCM, C75S BsCM, and $\mathrm{EcCM}^{a}$

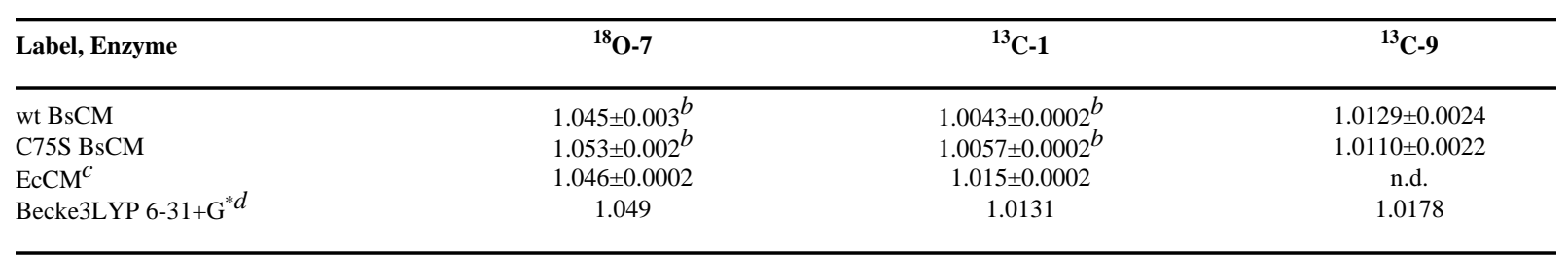

${ }^{a}$ In $50 \mathrm{mM}$ potassium phosphate buffer, $\mathrm{pH} 7.5$ and $22^{\circ} \mathrm{C}$. KIEs are corrected by division by the observed secondary kinetic isotope effect at $\mathrm{C} 10$, which was measured to be $1.0009 \pm 0.0001$ for wild-type BsCM, 1.0016 \pm 0.0002 for the C75S variant, and $1.0033 \pm 0.0001$ for EcCM.

$b_{\text {Ref. } 9}$

$c_{\text {n.d., not determined. }}$

$d_{\text {Calculated at } 298.15 \mathrm{~K}}$ 
Table 2

Kinetic isotope effects on the thermal rearrangement of chorismate ${ }^{a}$

\begin{tabular}{cccc}
\hline Label, Product & ${ }^{\mathbf{1 8} \mathbf{O}-\mathbf{7}}$ & ${ }^{\mathbf{1 3}-\mathbf{1}}$ \\
\hline prephenate & $1.0482 \pm 0.0005$ & $1.0118 \pm 0.0004$ \\
Becke3LYP 6-31+G ${ }^{* b}$ & 1.0427 & 1.0119 & $1.07 \pm 0.04$ \\
4-hydroxybenzoate & $1.0374 \pm 0.0005$ & 0.87 & $1.0113 \pm 0.0004$ \\
Becke3LYP 6-31+G* ${ }^{*} b$ & 1.0465 & 1.0022 & $1.85 \pm 0.06$ \\
\hline
\end{tabular}

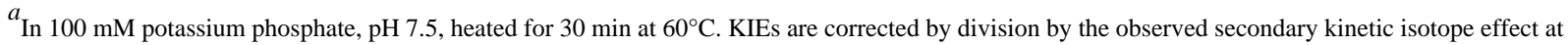
$\mathrm{C} 10$, which was measured to be $1.0011 \pm 0.002$ for the formation of both prephenate and 4-hydroxybenzoic acid. The buffer concentration for the deuterium kinetic isotope effects was $200 \mathrm{mM}$.

${ }^{b}$ Calculated at $333.15 \mathrm{~K}$ (see supplementary material).
} 